\title{
The Role of the Ministry of Law and Human Rights of the Republic of Indonesia in the Competition of Professional Football League in Indonesia
}

\author{
By Eko Noer Kristiyanto* \& Yusup Suparman ${ }^{\dagger}$
}

\begin{abstract}
The Implementation of professional football competition has a positive contribution to the objectives of the state, particularly efforts to promote the general welfare. The Implementation of professional football competition is associated with the legal system of transnational FIFA and the national legal system of Indonesia. The two legal systems have points of contact in which potential conflicts emerge. This paper tries to explain how exactly the position and role of national legal system in the professional football competition in order to support the realization of common prosperity, by comparing the function and role of the legal system in the implementation of the football competition. It turned out that the national legal system and FIFA legal system have their respective roles, the two are complementary. If both are in harmony and synergy, they will contribute positively to the promotion of the general welfare.
\end{abstract}

Keywords: Transnational Law, FIFA, Football, National Law, The General Welfare.

\section{Introduction}

One of the most important goals of the formation of a country is to prosper its people; even the Republic of Indonesia affirms it in the state constitution. The 1945 Constitution of the Republic of Indonesia is also called an economic constitution. One of its most important characteristics as an economic constitution is that it contains the idea of a welfare state. The main objective of the Indonesian state in the Republic of Indonesia's 1945 Constitution is to advance public welfare. The state is obliged to promote public welfare (promoting public welfare) and maximize social welfare (maximizing social welfare). The state has the function of creating sufficient terms and conditions and infrastructure to obtain its welfare (Yamin 1960: 298). The government is formed not to create public welfare, but to promote public welfare. Public welfare is something that is to be pursued continuously in the context of the development of the times (Goodin 1988: 22). The parameters also involve many aspects, but certainly the most important is the economic aspect. In the context of the welfare state, the state is obliged to ensure the availability of access to prosperity for its citizens. The state's efforts to realize public prosperity cover various fields of life in broad perspectives and dimensions, including guaranteeing activities that stimulate the economy of society, professional sports activities, sports in a global context that are increasingly modern and penetrate the industrial and economic sectors, as well as being a

\footnotetext{
${ }^{*}$ Researcher, Ministry of Law and Human Rights of Republic of Indonesia, Indonesia. ${ }^{\dagger}$ Officer, Ministry of Youth and Sports of Republic of Indonesia, Indonesia.
} 
means of advancing public welfare through income distribution and economic determination from various walks of life through various sectors.

The theory of legal pluralism recognizes what is called a transnational legal system in addition to national and international legal systems. The transnational legal system that was used as a guideline by the communities in the world turned out to be in accordance with the sports law system implemented by international sports federations to carry out their activities, including the organization of professional football competitions controlled by a legal system established by FIFA. In its implementation, it turns out that this transnational legal system has an interface with the applicable national legal system. In ideal conditions, these two systems should support and complement each other. Moreover, the state and FIFA actually have the same goals in the context of advancing and improving welfare.

Based on the above explanation, it is interesting to examine the position of the national legal system and the FIFA legal system whose existence is recognized in the transnational legal system. Football is regulated, controlled and subject to FIFA regulations (Pandjaitan 2011: 210-116). On the other hand, football cannot be carried out without permission from the state, because football is played on stadium fields in the sovereignty of a country. Synergy between the state and federation is very important in the implementation of a football match, especially the state and FIFA that also have the same goal of advancing well-being. Professional football competition can be a rational solution to strive for that goal. If FIFA and its legal system regulate the implementation of professional football competitions around the world, then what is the real role of the national law in the implementation of professional football competitions in Indonesia?

\section{Research Methods}

The research method used in this paper is the normative legal research method. The normative legal research method basically examines the rules of law and legal principles (Manan 1993: 7). Normative research will try to find a rule of law, legal principles, and legal doctrine to answer legal issues that are faced specifically related to theories about legal pluralism and the existence of a transnational legal system that is the basis for the enactment of the FIFA legal system in the context of universal football implementation throughout the world. It explains how the implementation of professional football competitions has contributed positively to one of the country's goals stated in the constitution, which promotes public welfare. This study examines the problem by referring to secondary data carried out by literature studies of legal materials and non-legal materials relating to the research title. Secondary legal materials in question are doctrines, teachings of experts, scientific work of experts, news and results of interviews of related parties obtained from newspapers and internet sites that are relevant to the research title (Soekanto 2001).

The above data is collected through library research, research through internet media, in this case the author focuses on the context of football competition in 
order to advance public welfare, then explains what and how the role of the national law in the implementation of football competitions is.

\section{Discussion}

Legal Pluralism and FIFA Legal System

\section{$\underline{\text { Legal Pluralism }}$}

As explained earlier, in many ways the implementation of professional football competitions has a positive correlation with efforts to promote the general welfare. It is important to understand that professional football competition is not controlled by the state, football has its own rules that make football have sovereignty and a system controlled by FIFA as the main football organization. The FIFA system operates in a transnational system and needs to be understood in terms of its boundaries and state jurisdiction. It is because if there is a conflict, the existence of professional football competition is threatened and efforts to promote public welfare through football are disrupted (Kristiyanto 2015a).

According to Jimly Asshiddiqie in today's modern democratic system, the power system in the life of the state can be distinguished in three regions or domains, namely the state (state), market (market), and society (civil society). The three regions or domains of power have their own logic and law. This is what Jimly calls an organizational imperative theory. The organizational imperative theory is closely related to pluralist sovereignty theory, which states that sovereignty does not always have to be interpreted absolutely and belongs to the state alone. Sovereignty can be decentralized to communities that are able to do so to advance public welfare without having to harm sovereignty itself (Ashiddiqie 2005: 43).

The theory of pluralist sovereignty gave birth to legal pluralism, namely the presence of a transnational legal system other than the national legal system and the international legal system. Transnational law is a law formed by an international community that is not a state (international society) and applies to its community across administrative borders. The view of sovereignty and legal pluralism is a criticism of the views of absolute sovereignty as well as criticism of the view of monism because the existence of a legal system originating from sources other than the state is a reality (Pandjaitan 2011). The legal view of pluralism recognizes that every community or organized social group also has a system and legal system in accordance with their needs and are autonomous. In the context of globalization like now, the relevant sovereignty theory is not an absolute sovereignty theory but a pluralist sovereignty theory in which the state is not the only important role in carrying out state dynamics, the principle is that the implementation of sovereignty can be decentralized to society. This is in line with what was expressed by Yudha Bhakti Ardhiwisastra, namely that the jurisdiction in its implementation will be limited by the rules that apply in relations between countries (Ardhiwisastra 2003: 13) 
If state power exceeds the power of civil society and markets, democracy will not grow because it is too dictated and controlled by state power. If market power is too strong, it is the power of money or capitalists that determines the life of society and the state. Meanwhile, if the one that is too dominant is the power of civil society while the state and the market are weak, what will happen is chaos, mess, less government, which develop without clear direction. Therefore, democracy will grow ideally if the three things grow in a balanced manner, equally strong and mutually influential in functional and synergic relationships.

Then it can be concluded that the transnational legal system is formed as a consequence of the birth of a global society that eliminates administrative boundaries of a country (borderless), which then gives birth to agreements and international cooperation in all fields including sports such as football. In this context, the so-called transnational legal system in the field of sports is commonly referred to by experts as Lex Sportiva, in the football sports branch known as the FIFA legal system, which includes statutes and all derivative regulations formed to organize integrated football matches universally, including professional football competitions in each FIFA member state.

\section{FIFA Legal System}

In the context of pluralist sovereignty theory and the theory of organizational imperatives described earlier, FIFA as an international football federation and all its confederations and associations can be referred to as a civil society and the market as well as the state that is the government in the context of the Indonesian government. The Federation Internationale de Football Association (FIFA) is an organization whose legal entity status as a single international football federation that was established on 21 May 1904 in Paris France and registered under article 60 of the Swiss Civil Code (William 2015). FIFA has a special and unique institution, the International Football Association Board (IFAB), as the only institution that has the absolute authority to make and or update the laws of the game for organizing football matches in the world, which Ken Foster calls Lex Ludica. All FIFA members must obey and implement the laws of the game in every professional football match. This applies universally to any party that plays football as Sui Generis. Lex Ludica is part of Lex Sportiva, Lexica Ludica ensures that football is carried out according to the rules while Lex Sportiva ensures the organizing process so that Lexus Ludica can run according to the mechanism. Unlike Lex Ludica, Lex Sportiva can be in contact with the national legal system of a country where football is carried out, especially things that are licensing because after all football can only take place in a field that is the territorial jurisdiction of a country. Lex Sportiva is part of the global sports law regime, global sports law is defined as an independent and transnational legal order created by global private institutions to regulate, manage and organize global and sovereign football competitions. Ken Foster formulates that Lex Sportiva as a global sports law is an autonomous and independent legal regulation, which crosses state jurisdiction, which is formed by global private institutions that regulate and control sport internationally (Foster 2003). Its main characteristic is 
that global sports law is a contractual rule with its binding power based on an agreement to hand over power and rights to the authority and jurisdiction of the international sports federation. In addition, Lex Sportiva as a global sports law is not regulated by the national legal system.

\section{Football and General Welfare}

In the concept of the welfare state, the task of government in the rule of law is not only to run the government, but more than that it must improve the welfare of the community in order to achieve the goals of the state. These efforts are carried out through national development that is multi complex. The state is obliged to the terms and conditions and infrastructure needed so that its citizens have adequate access to their welfare, including in terms of sports. Sports in the global context are increasingly modern and not merely becoming activities related to health but also industry and economy, as well as being one of the factors or means to advance public welfare through the distribution of income at the grassroots level to the elite level (Anggriani 2003: 41).

The latest phenomenon related to the relationship between sports and the economy is the holding of the 2016 National Sports Week (PON) event in West Java. The economic benefits that occured during the operation of the PON are estimated to reach 1.6 trillion rupiahs. Business fields affected by sports events include hospitality, infrastructure, culinary, transportation, convection, crafts. Economic distribution does not only involve large entrepreneurs but involves MSMEs. This does not include informal matters that are considered trivial such as parking, guide services, etc. In the long run, even professionally managed sporting events can be directed to sport tourism. According to the world tourism organization namely United World Tourism Organization (UNWTO) and International Olympic Committee (IOC), the synergy between tourism and sports has the ability to grow a sustainable economy by creating jobs and increasing people's income. Sports tourism is now recognized as a multi-billion dollar business. The economies of cities, regions and even countries are affected. Even in some countries, sports can contribute 25 percent of all income generated by the tourism industry. For example, the 2014 World Cup event in Brazil was able to reap economic profits of around 34 trillion from the tourism sector (Simatupang and Pariwisata 2016).

The sports industry is an industry with great potential to mobilize the economic behavior of the community collectively. Thus, the sports industry has the potential to be a sector that can have a significant impact on poverty reduction and overcoming unemployment. The sports industry needs to be encouraged and supported through a series of systematic policies from central and regional governments, communities, and investors.

Professional football competition as a competition involving the most popular sports throughout the world contributes a huge opportunity for the promotion of public welfare, not only in countries where football competitions are rolled out, but also in countries that make football competitions an economic commodity. For example, the English Premier League is able to provide the economic 
determination for other countries, including Indonesia, through live television broadcasts.

Professional football competitions create enormous employment opportunities for football players, football managers, football businessmen, culinary entrepreneurs, convection entrepreneurs, transportation entrepreneurs, media entrepreneurs, hotel entrepreneurs, infrastructure entrepreneurs, and other economic actors. There are more than 270 million people in the world active in football, including football players and devices. Of the 85 million players active in Asian football, there are around 7.094,000 players in Indonesia.

The Tangent Point between the FIFA Legal System and the National Legal System

Professional football competition is run with a set of rules that are universal. These rules are derived from the FIFA legal system consisting of FIFA statutes and all derivatives called Lex Sportiva, which consists of the laws of the game as Lex Ludica and Lex Sportiva itself, which is enforced to ensure that professional football competitions in each country run according to the mechanism.

In its implementation it turns out that this FIFA system has intersection, intersections of laws with national law. The intersection does not occur in the context of enforcing the laws of the game as Lex Ludica that is fully FIFA authority but occurs in the enforcement of Lex Sportiva in general, namely things and mechanisms and ways to organize football competitions in addition to the laws of the game. The thing meant is related to licensing and other administrative matters. The condition is when a provision has been regulated by the FIFA legal system, but it turns out that the provision is also related to the legal system in the country of Indonesia. For example: FIFA requires that every professional football club becomes a legal entity and corporate/corporate, it turns out that the legal entity referred to by FIFA has been regulated by the Indonesian national law through Law Number 40 of 2007 concerning Limited Liability Companies, as well as other things that are desired by FIFA and also regulated by Indonesian national law. Then, it can be seen that the implementation of football competitions in a country intersects with two legal systems namely the national legal system and the transnational legal system (sports law). In this paper, it will be limited to anything football or the FIFA legal system must submit without conditions because de jure is the absolute jurisdiction of Indonesia's national legal system. It is because the legal world in the field of sports does not form a world of law that is completely separate from state law. If the rules governing sport are made by international private sports organizations, sports cannot avoid the application of state law where sports have competed. Sports actors are subject to general legal rules that apply in their country such as regulations on the legality of legal entities, health, security, contract law, laws related to tax provisions, labor law and so on. In the context of organizing football, the influence and jurisdiction of state law are inherent especially in matters relating to administration and licensing, which include, among others: 
The Legal Entity Forms a Limited Liability Company for Professional Football $\underline{\text { Clubs }}$

In the context of professional football, a football club is a profit / profitoriented company. The status of a professional club legal entity as a corporation must be clear according to legal aspects related to football clubs regulated by FIFA regulations to federation technical rules in a competition, because what is desired is a company with a profit orientation. Therefore professional football clubs must be in the form of a Limited Liability Company (PT) in accordance with Law Number 40 of 2007. Then the management structure of professional football clubs is like PT in general, including editorial board and board of commissioners. These football clubs also have shared and held a GMS, not only that, programs related to corporate social responsibility as regulated by the Limited Liability Company Law also become a requirement that must be fulfilled by football clubs while undergoing verification as competition participants . Conventionally professional football clubs optimize revenues through match ticket sales, sponsorships, sales of knick-knacks, TV broadcasting rights, and buying and selling players. The status of a football club as a limited liability company is registered at the Directorate General of General Legal Administration-Ministry of Law and Human Rights of the Republic of Indonesia (Kristiyanto 2015a).

\section{$\underline{\text { Immigration and Employment Status for Foreign Football Players }}$}

Foreign players in professional football competitions are a necessity, even the presence of foreign players is always the main attraction in a football competition. The origin of foreign players whose services are used by football clubs participating in football competitions in Indonesia covers four continents, there are foreign players from the continent of Africa, the Americas, the continent of Asia and some even from the continent of Australia. As foreigners working in Indonesia, of course these foreign players must submit to Indonesian national law that regulates immigration and employment. This is clear evidence that national law actually has an important role in professional football competition. The players who do not comply with the rules are not only unable to make a living freely but are also threatened with deportation. A concrete example is seen in the findings revealed in September 2016, that dozens of foreign players were playing for participating clubs in Torabika Football Championship without Temporary/ Limited Stay Permit (KITAS) which is a requirement for foreign workers to work in Indonesia. This finding is not disputed by PT. GTS (Gelora Trisula Semesta) as the operator of competition also by several clubs reinforced by troubled foreign players according to a list released by sports NGOs Save Our Football (SOS).

The majority of foreign players use visa on arrival, even though visa on arrival is only valid for 30 days and cannot be used for work, especially for the ISC competition which takes up to 9 months. Do not forget the immigration violations that they have committed at the same time also violate regulations in the field of employment, because the administrative requirements related to immigration are a requirement to get work permits in Indonesia. 
Immigration-related violations are absolutely a state jurisdiction specifically enforced by the Directorate General of Immigration-the Ministry of Law and Human Rights of the Republic of Indonesia.

The threat of the government to deport illegal players is a logical consequence that must be accepted, based on Article 42 of Law Number 6 Year 2011 concerning Immigration, which states that administrative actions (including deportation) can be imposed to foreigners who do not respect or obey regulations or current regulation (Kristiyanto 2015a).

\section{$\underline{\text { Match Permissions }}$}

The stage of the competition permit management really shows the condition of the enactment of the principle of "no football without state permission". Even though football is controlled and subject to the FIFA system, football matches require a field and stadium that are owned and are under the sovereignty of a country. The most important thing that must be obtained by the organizers of the match before starting a match is the permission of the crowd from the police. For regional matches, permits are issued by the local police through the intelligence department, but previously the organizers have to coordinate with the police station where the competition is held. When taking care of the permit to the police station, the organizing committee must attach a recommendation for permission to use the place, a readiness letter for medical personnel and the fire department. If the affairs in the police station are finished, the process will proceed to the regional police. The regional police will also request a letter from the center, namely the central organizer, namely the federation (PSSI) and competition operator. For class competitions at the national level involving competitions between regions / between provinces, those who issue letters of recommendation for permits are the National Police Headquarters, police and police stations only issue recommendations. The permission of the relevant regional government is issued by the youth and sports agency. The licensing process shows the country's sovereignty over football matches in its territory (Kristiyanto 2015b).

\section{$\underline{\text { Registration of Exclusive Rights }}$}

In practice, football club get revenue from four sectors of income, namely advertising and sponsorship, match ticket sales, television broadcasting rights and merchandise sales that are closely related to brands. Branding or brand is one way for the football industry in the entire world to thrive. Almost every year, various institutions audit the football club brands in the world. Then the brand is capitalized. In the context of business, brands certainly have an important role to play, brands are associated with the exclusive rights of professional football club to optimize sales from official merchandise issued by the club in question. Institutions which currently have authority related to brand registration are the Ministry of Law and Human Rights, specifically the Directorate General of Intellectual Property. It could be that the brand or name of a football club is the only asset truly owned by a football club in Indonesia. It is obviously very difficult 
to find football clubs in Indonesia that have physical assets such as stadiums or other facilities (Kristiyanto 2015a).

\section{Role of National Law in Organizing Professional Football Competition}

The main factor for the law to be able to play a role in economic development is whether the law is able to create "stability", "predictability" and "fairness". Therefore, the law should play a role in economic development, the law must be a guide and reference in development included in the implementation of professional football competitions that support the promotion of public welfare (Rajagukguk 2000).

FIFA has full authority and sovereignty in organizing systems, rules and mechanisms to ensure that the laws of the game are carried out and obeyed by all its members when conducting professional football competitions. This is what is called Lex Sportiva, including the laws of the game as Lex Ludica. On the contrary, the state does not have any authority regarding the laws of the game. Even though FIFA has full sovereignty over the football system, but FIFA still cannot hold football without the presence of the state. This is related to the existence of football fields and other supporting infrastructure which of course is in the territory of sovereignty and jurisdiction of a country, then it can be said that there is no football without state permission. In this context, there is a tangent point between the state and its national legal instruments, especially related to administration and licensing, with the FIFA legal system. Likewise, in the framework of relations between clubs, players with clubs, clubs and competition managers and other parties such as TV stations and sponsors; civil relations do not only refer to FIFA rules but also the principles of civil law in Indonesia.

So that in the implementation of a globally integrated professional football competition and the contribution to the promotion of general welfare, national law and transnational law are applied, both of these legal systems have their own sovereignty and jurisdiction. Although they have tangible points, they cannot intervene in the sense that they negate and deny each other because at the ideal level both will complement each other and support the implementation of professional football competitions. The state can intervene in terms of showing its influence but in matters that are very limited and truly necessary (Ashiddiqie 1994). In the context of football as a global sport run by society, the state should not interfere too far. State institutions should not be formed with the intention of taking transfer of functions that naturally can be done effectively and efficiently by society.

\section{Closing Remarks}

Professional football competition has an important meaning for Indonesia, especially related to the state's goal to advance public welfare. In professional football competition, national law has a strategic role, namely related to the provision of infrastructure, licensing and other administrative matters regulated by 
Indonesian law and related to professional football competition. In terms of this administration, it turns out that the Ministry of Law and Human Rights of the Republic of Indonesia has an important role because it handles three important things, namely the residence permit of foreign players, registration of professional football club legal entities, and brand registration as exclusive rights of professional football clubs. Football is regulated, controlled and subject to FIFA statutes so that the implementation of football is universally integrated through the FIFA legal system, but football players in Indonesia cannot privilege themselves regarding matters that have been regulated by Indonesian law such as taxes, employment, immigration, legality of legal entities, crowd permits and so forth. Government authority and intervention as a state must not violate the sovereignty of society, the existence of society. Its sovereignty has its own laws (the laws of the game) which ideally do not violate the sovereignty of the state and apply to the community to solve their own affairs, and require national law for matters that are not regulated by society law, such as the legality of club legal entities, taxes, immigration and so forth. The national legal system and the FIFA legal system should complement and support each other and do not cancel each other, because if both are harmonious and synergistic, they will contribute positive efforts to advance public welfare.

\section{References}

Anggriani J (2003) Hukum Internasional [International Law]. Bandung: Alumni.

Ardiwisastra (2003) Hukum Internasional [International Law]. Bandung: Alumni.

Asshiddiqie J (1994) Gagasan Kedaulatan Rakyat dalam Konstitusi dan Pelaksanaannya di Indonesia [The Idea of People's Sovereignty in the Constitution and its Implementation in Indonesia]. Jakarta: Ichtiar Baru.

Asshiddiqie J (2005) Kemerdekaan Berserikat Pembubaran Partai Politik dan Mahkamah Konstitusi [Freedom of Association The Dissolution of Political Parties and the Constitutional Court]. Jakarta: Konstitusi Press.

Kristiyanto EN (2015a) Negara Tanpa Sepak Bola. [Country without Football]. OPINI, HU Pikiran Rakyat, Bandung.

Kristiyanto EN (2015b) Sepak Bola dan Kesejahteraan Umum. [Football and Public Welfare]. OPINI, HU tribun jabar.

Foster K (2003) Is there a global sports law? The Entertainment and Sports Law Journal 2(1): 1 .

Goodin RR (1988) Responsibility Right \& Welfare, The Theory of the Welfare State. Colorado: Westview Press.

Manan B (1993) Penelitian Terapan di Bidang Hukum. [Applied Research in the Field of Law]. BPHN, Jakarta 9-11.

Pandjaitan Hinca IP (2011) Kedaulatan Negara VS Kedaulatan FIFA [State Sovereignty VS FIFA Sovereignty]. Jakarta: PT Gramedia Pustaka Utama.

Rajagukguk E (2000) Peranan Hukum di Indonesia: Menjaga Persatuan, Memulihkan Ekonomi dan Memperluas Kesejahteraan Sosial [The Role of Law in Indonesia: Maintaining Unity, Restoring Economy and Expanding Social Welfare]. Jakarta: UI.

Simatupang V (2016) Pariwisata Olah-Raga [Sports Tourism), HU Pikiran Rakyat Bandung. 
Soekanto S, Sri M (2001) Penelitian Hukum Normatif: Suatu Tinjauan Singkat. [Normative Legal Research: A Brief Review]. Jakarta: Raja Grafindo Persada.

Yamin M (1960) Naskah Persiapan Undang-Undang Dasar Negara Republik Tahun 1945[Manuscript for Preparation of the Republic of 1945 Constitution]. Jakarta: Jajasan Prapantja. 
